\title{
Pengaruh Karakteristik Sedimen terhadap Distribusi dan Akumulasi Logam Berat Pb dan Zn di Perairan Sungai, Estuaria, dan Pantai
}

\author{
Najamuddin 1*, Irmalita Tahir1, Rustam E. Paembonan' dan Inayah² \\ 'Program Studi Ilmu Kelautan, Fakultas Perikanan dan Kelautan, Universitas Khairun \\ 2Program Studi Manajemen Sumberdaya Perairan, Fakultas Perikanan dan Kelautan, \\ Universitas Khairun \\ Jl. Raya Pertamina, Ternate, 97719 \\ Email : najamuddin313@gmail.com
}

\begin{abstract}
Abstrack
Sediment Characteristics Influence on the Distribution and Accumulation of Heavy Metals Pb and Zn in the River, Estuary, and Coastal Waters
\end{abstract}

The purpose of the study was to analyze the effect of surface sediment characteristics including texture, organic carbon content, and redox potential of sediments on the distribution and accumulation of heavy metals $\mathrm{Pb}$ and $\mathrm{Zn}$ in three different water zones of each river, estuary and coast. Sediment texture was determined by pipette method, organic carbon content in sediments using Walkley and Black method, redox potential of sediments measured by Eh Meter, and concentrations of heavy metals $\mathrm{Pb}$ and $\mathrm{Zn}$ in sediments with Atomic Absorption Spectrophotometer with graphite furnace system. The results showed that the distribution and accumulation pattern of heavy metals $\mathrm{Pb}$ was similar to $\mathrm{Zn}$ where the highest concentration was in the coastal waters zone and the lowest was in the estuary waters zone. Sediment texture in the three zones of the dominant was sand. The percentage of organic carbon content in sediments ranges from 1.63-3.25\% and the sediment redox potential was classified as reduction and transition zones. The parameters of texture, organic carbon content, and sediment redox potential have a significant influence on the distribution and accumulation of heavy metals $\mathrm{Pb}$ and $\mathrm{Zn}$ in sediments in all three water zones.

Keywords: heavy metal; texture; organic carbon; redox potential

\begin{abstract}
Abstrak
Tujuan penelitian adalah menganalisis pengaruh karakteristik sedimen permukaan meliputi tekstur, kandungan karbon organik, dan potensial redoks sedimen terhadap distribusi dan akumulasi logam berat $\mathrm{Pb}$ dan $\mathrm{Zn}$ di tiga zona perairan berbeda masing-masing sungai, estuaria, dan pantai. Tekstur sedimen ditentukan dengan metode pipet, kandungan karbon organik dalam sedimen dengan metode Walkley and Black, potensial redoks sedimen diukur dengan Eh Meter, dan konsentrasi logam berat $\mathrm{Pb}$ dan Zn dalam sedimen dengan Spektrofotometer Serapan Atom dengan sistem graphite furnace. Hasil penelitian menunjukkan pola distribusi dan akumulasi logam berat $\mathrm{Pb}$ serupa dengan $\mathrm{Zn}$ dimana konsentrasi tertinggi di zona perairan pantai dan terendah zona perairan estuaria. Tekstur sedimen pada tiga zona perairan dominan berupa fraksi pasir (sand). Persentase kandungan karbon organik dalam sedimen berkisar antara 1,63-3,25\% dan nilai potensial redoks sedimen termasuk kategori zona reduksi dan transisi. Parameter tekstur, kandungan karbon organik, dan potensial redoks sedimen memberikan pengaruh nyata terhadap distribusi dan akumulasi logam berat $\mathrm{Pb}$ dan $\mathrm{Zn}$ dalam sedimen pada ketiga zona perairan.
\end{abstract}

Kata kunci: logam berat; tekstur; karbon organik; potensial redoks 


\section{PENDAHULUAN}

Logam berat masuk ke dalam perairan mengalami beberapa proses seperti pengendapan, pengenceran, pelarutan, dispersi, dan akumulasi akibat proses fisika, kimia, dan biologi. Salah satu bentuk perilaku logam berat dalam perairan adalah mudah terikat pada bahan organik menyebabkan logam berat berbentuk terlarut berubah menjadi logam berat bentuk partikel kemudian terdeposisi dan terakumulasi di sedimen dasar perairan. Akibatnya sering dijumpai kadar logam berat dalam sedimen lebih tinggi dibanding dalam kolom air bahkan menurut Bryan and Langston, 1992 bahwa konsentrasi logam berat dalam sedimen bisa mencapai 3-5 kali lebih tinggi dari konsentrasi logam berat dalam kolom air di atasnya.

Tingkat konsentrasi logam berat dalam sedimen sangat penting diketahui karena konsentrasi logam berat dalam sedimen menggambarkan tingkat akumulasi logam berat pada suatu periode waktu tertentu. Tingkat akumulasi logam berat dalam sedimen ditentukan oleh faktor fisika kimia sedimen. Perbedaan karakteristik sedimen menyebabkan perbedaan kemampuan sedimen dalam mengakumulasi logam berat sehingga mempengaruhi pola distribusinya. Beberapa karakteristik fisika kimia sedimen yang paling utama menentukan distribusi dan akumulasi logam berat dalam sedimen adalah tekstur atau ukuran partikel sedimen, kandungan karbon organik, dan kondisi oksidasi reduksi dalam sedimen (Rainbow, 2006).

Stecko dan Bendell-Young (2000) mengemukakan bahwa ketersediaan logam berat dalam sedimen berkaitan erat dengan sifat dan Ukuran sedimen. Sedimen yang mengandung jumlah mineral lempung (clay) dan karbon organik tinggi cenderung mengakumulasi logam berat lebih tinggi, karena senyawa-senyawa tersebut memiliki sifat mengikat logam. Demikian pula komponen oksida besi, mangan dan bahan organik lainnya merupakan komponen geokimia yang paling penting dalam mengontrol pengikatan logam berat dalam sedimen.
Kandungan karbon organik memiliki hubungan yang positif dengan konsentrasi logam berat dalam sedimen. Selain itu, kandungan logam berat dalam sedimen juga bergantung pada komposisi kimia dan mineral sedimen. Konsentrasi logam berat dalam sedimen umumnya lebih tinggi pada sedimen yang bertekstur liat, lumpur, pasir berlumpur, dan campuran ketiganya dibanding sedimen berupa pasir murni. Hal ini disebabkan adanya gaya tarik elektro kimia partikel sedimen yang lebih kuat pada sedimen yang lebih halus (Sanusi, 2006). Fraksi sedimen yang halus memiliki area permukaan yang lebih luas sehingga dapat mengikat zat terlarut lebih banyak. Faktor lain yang juga berperan adalah kandungan bahan organik yang lebih tinggi pada fraksi sedimen yang halus sehingga logam berat membentuk ikatan dengan partikel organik.

Distribusi dan akumulasi logam berat dalam sedimen, selain dipengaruhi oleh tekstur dan kandungan bahan organik, juga ditentukan oleh mekanisme reaksi oksidasireduksi dalam sedimen dan ketersediaan oksigen terlarut dalam air jebakan (interstitial water) serta pH sedimen (Sanusi, 2006). Aspek lain yang berpengaruh terhadap distribusi dan akumulasi logam berat adalah faktor perbedaan musim (Najamuddin et al., 2016) dan perubahan ekosistem (Najamuddin dan Surahman, 2017).

Karakteristik fisika kimia sedimen pada tiga zona perairan masing-masing sungai, estuaria, dan pantai cenderung selalu berbeda karena perbedaan kondisi pada tiga perairan tersebut. Namun data dan informasi terkait distribusi dan akumulasi logam berat pada tiga zona perairan tersebut dalam satu kajian yang terintegrasi masih kurang sehingga menjadi dasar dilakukannya penelitian ini.

Tujuan penelitian adalah menganalisis pengaruh parameter fisika kimia sedimen yang meliputi tekstur, kandungan bahan organik, dan potensial redoks sedimen terhadap distribusi dan akumulasi logam berat $\mathrm{Pb}$ dan $\mathrm{Zn}$ dalam tiga zona perairan berbeda (sungai, estuaria, dan pantai). 


\section{MATERI DAN METODE}

Pengumpulan data dilakukan pada 17 titik sampling yang dibagi dalam tiga zona perairan yaitu perairan sungai dengan titik sampling 1-3, perairan estuaria dengan titik sampling 4-10, dan perairan pantai dengan titik sampling 11-17. Peta lokasi penelitian dan sebaran titik sampling disajikan pada Gambar 1. Sedimen diambil pada lapisan permukaan kira-kira pada lapisan 0-20 cm dengan Ekman Grab Sampler (distribusi titik sampling ditunjukkan pada Gambar 1). Sampel sedimen sebanyak 500 gram dimasukkan ke dalam botol polyetilen. Botol polyetilen sebelumnya telah direndam dengan $\mathrm{HNO}_{3} 6 \mathrm{~N}$ dan selanjutnya dibilas dengan air suling. Sampel sedimen selanjutnya disimpan dalam ice box pada suhu $4{ }^{\circ} \mathrm{C}$. Setelah di laboratorium sampel sedimen dikeringkan dengan menggunakan alat freeze dryer pada suhu $-12^{\circ} \mathrm{C}$.

Pengambilan sampel sedimen, dilakukan pengukuran secara langsung parameter potensial redoks sedimen dengan Eh meter digital. Tekstur sedimen ditentukan dengan metode pipet. Konsentrasi karbon organik dalam sedimen dengan metode Walkley and Black (1934), konsentrasi logam berat $\mathrm{Pb}$ dan $\mathrm{Zn}$ dalam sedimen ditentukan dengan Spektrofotometer Serapan Atom dengan sistem graphite furnace.

Proses preparasi sedimen sebelum dianalisis logam beratnya dengan menimbang 5 gram sedimen yang sudah homogen selanjutnya dikeringkan dengan oven pada suhu $60{ }^{\circ} \mathrm{C}$ selama 24 jam. Sedimen dihaluskan dan dimasukkan ke dalam tabung reaksi lalu ditambahkan $10 \mathrm{ml}$ $\mathrm{HNO}_{3}$ (1:1) kemudian dipanaskan pada suhu $95{ }^{\circ} \mathrm{C}$ selama 15 menit, selanjutnya didinginkan lalu ditambahkan $5 \mathrm{ml} \mathrm{HNO}_{3}$ pekat dan dipanaskan selama 30 menit. Setelah itu ditambahkan $5 \mathrm{ml} \mathrm{HNO}_{3}$ secara berulang-ulang sampai reaksi terjadi secara sempurna. Dilakukan lagi pemanasan hingga volumenya mencapai $5 \mathrm{ml}$ lalu didinginkan kembali. Kemudian ditambahkan lagi $2 \mathrm{ml}$ aquabidest dan $3 \mathrm{ml} \mathrm{H} \mathrm{O}_{2}$ (30\%) kemudian dipanaskan beberapa menit lalu ditambahkan lagi $1 \mathrm{ml} \mathrm{H}_{2} \mathrm{O}_{2}$ dan pemanasan dilanjutkan sampai volume menjadi $5 \mathrm{ml}$ dan setelah itu didinginkan. Ditambahkan lagi 10 $\mathrm{ml} \mathrm{HCl}$ pekat lalu dipanaskan pada suhu 95 ${ }^{\circ} \mathrm{C}$ selama 15 menit, selanjutnya disaring dengan kertas saring whatman dan siap dianalisis dengan Atomic Absorption Spectrometry (AAS) varian ShimudzU-AA7000.

Penentuan tekstur sedimen yang terdiri dari sand, silt, clay (pasir, lanau, dan liat) kemudian diproyeksikan dalam segitiga tekstur sedimen dan dihitung persentasenya berdasarkan skala Wenworth. Analisis hubungan karakteristik sedimen (tekstur, kandungan karbon orgnik, dan potensial redoks sedimen) dengan distribusi dan akumulasi logam berat $\mathrm{Pb}$ dan $\mathrm{Zn}$ dianalisis menggunakan regresi linier.

\section{HASIL DAN PEMBAHASAN}

Konsentrasi logam berat $\mathrm{Pb}$ tertinggi ditemukan pada titik 1 yang berada pada zona perairan sungai sebesar 3,30 $\mathrm{mg} / \mathrm{kg}$ berat kering. Sumber potensial $\mathrm{Pb}$ dalam sungai berasal dari pemukiman, aktivitas pertanian, dan transportasi darat yang masuk ke dalam aliran sungai Jeneberang lalu terakumulasi di dalam perairan sungai. Konsentrasi yang tinggi juga ditemukan pada titik 14 yaitu pada perairan pantai sebelah utara estuaria Jeneberang.

Tingginya konsentrasi $\mathrm{Pb}$ dalam sedimen pada titik 14 karena dekat dengan aktivitas pelabuhan dan industri kapal yang berkontribusi menyumbang polutan logam berat $\mathrm{Pb}$ ke dalam perairan. Selain itu, sumber lain yang berpotensi menyumbang polutan logam berat $\mathrm{Pb}$ adalah keberadaan rumah sakit, hotel, dan mall di pesisir pantai Losari yang dekat dengan titik 14 serta aktivitas transportasi darat yang ikut menyumbang $\mathrm{Pb}$ dari buangan asap kendaraan karena TEL (tetra ethyl lead) digunakan sebagai peningkat nilai oktan bahan bakar sehingga buangan dari asap kendaraan dapat meningkatkan $\mathrm{Pb}$ dalam lingkungan perairan.

Konsentrasi terendah ditemukan pada titik 4 yang berada di zona perairan estuaria yaitu sebesar $0,449 \mathrm{mg} / \mathrm{kg}$ berat kering (Gambar 2). Diduga konsentrasi terendah Pb dalam sedimen pada titik 4 karena kuatnya proses pengadukan atau turbulensi massa air sehingga terjadi proses desorpsi logam 
dari sedimen ke dalam kolom air akibat proses resuspensi sedimen. Hal ini dikemukan oleh Lenzi (2008) bahwa resuspensi sedimen menyebabkan terjadinya desorpsi atau pelepasan logam di dalam kolom air sebagai dampak lanjutan yang muncul adalah perubahan pola interaksi logam berat terlarut dan partikulat dalam kolom air. Mekanisme tersebut menggambarkan kondisi yang selalu terjadi di perairan estuaria sehingga perilaku logam berat di perairan estuaria sangat spesifik dan dinamis.

Lebih Ianjut Lenzi (2008) menyatakan bahwa efek resuspensi bergantung pada musim dan kondisi dasar perairan. Misalnya efek resuspensi berupa peningkatan nitrogen yang terjadi secara tiba-tiba akibat percampuran antara air jebakan dalam sedimen (interstitial water) dengan kolom air, namun jumlah yang dilepaskan dipengaruhi oleh gradien difusinya dalam periode waktu yang lama. Resuspensi sedimen dengan karakter permukaan yang halus meningkatkan oksidasi dalam sedimen sehingga terjadi peningkatan nilai Eh, penurunan bahan organik namun tidak menunjukkan peningkatan nutrien dan konsumsi oksigen secara signifikan dalam kolom air.

Pola distribusi dan akumulasi logam berat $\mathrm{Pb}$ menunjukkan penurunan konsentrasi dalam perairan estuaria, hal mengindikasikan bahwa sumber logam berat $\mathrm{Pb}$ dalam estuaria berasal dari perairan pantai dan sungai. Variasi distribusi dan akumulasi logam berat $\mathrm{Pb}$ di perairan estuari ditentukan oleh input material dari daratan melalui aliran sungai dan dari laut melalui siklus pasang surut dan proses fisika-kimia-biologi yang berlangsung di dalam estuaria.

Rata-rata total konsentrasi $\mathrm{Pb}$ dalam sedimen di lokasi penelitian sebesar 1,987 $\mathrm{mg} / \mathrm{kg}$ berat kering. Penelitian ini sejalan dengan hasil penelitian Werorilangi et al., 2013 yang menyatakan bahwa distribusi logam $\mathrm{Pb}$ di sekitar perairan pantai Kota Makassar termasuk pantai Losari cukup tinggi. Perbandingan hasil penelitian ini dengan beberapa penelitian lain disajikan pada Tabel 2.

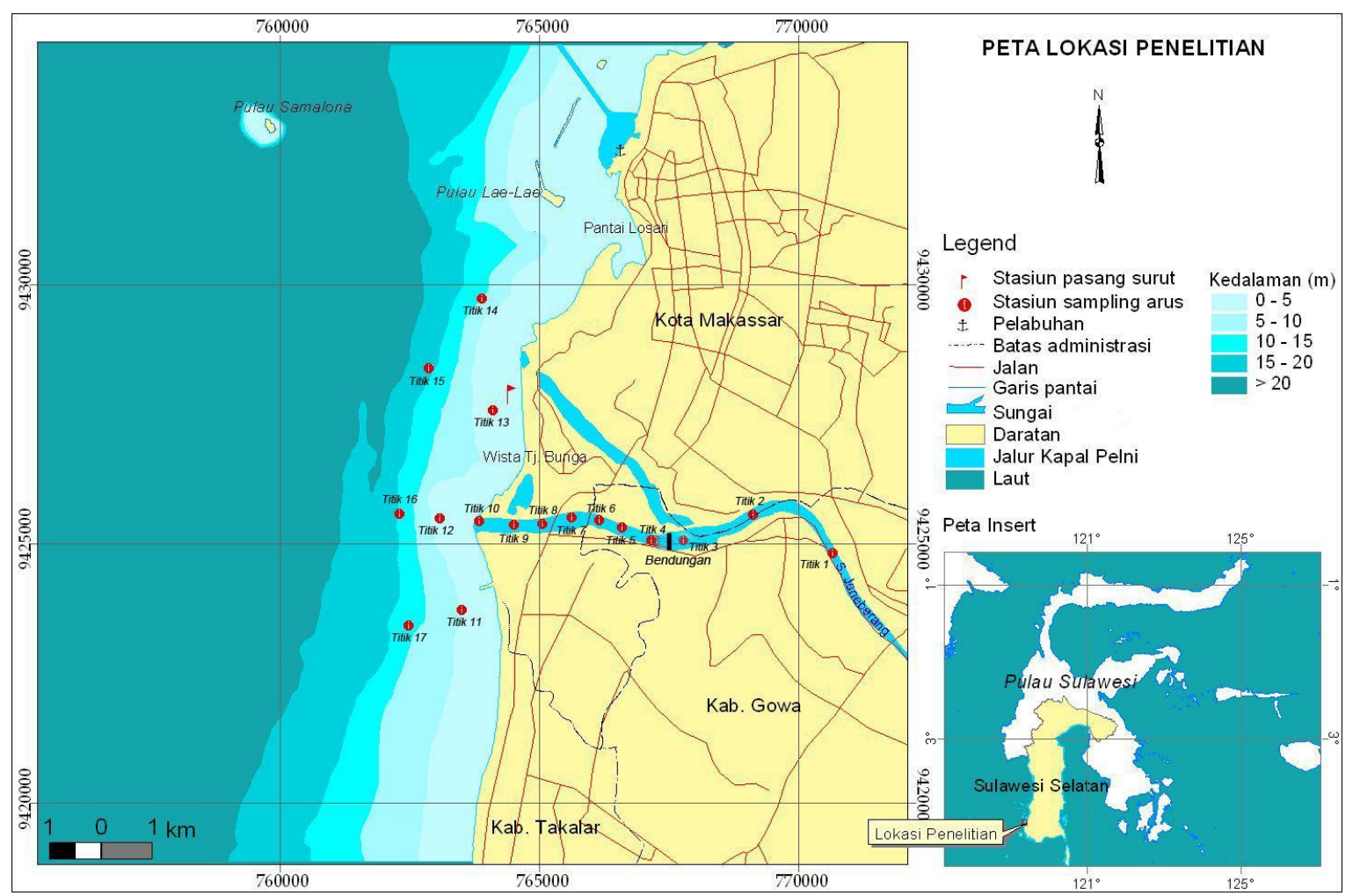

Gambar 1. Peta lokasi penelitian dan sebaran titik sampling di tiga zona perairan (Sumber peta; diolah dari data Citra Landsat 7 ETM+) 
Konsentrasi logam berat $\mathrm{Pb}$ dalam sedimen pada semua titik sampling masih di bawah kadar $\mathrm{Pb}$ alami dalam kerak bumi, sebagaimana Mohiuddin et al., 2010 menyatakan bahwa konsentrasi alami $\mathrm{Pb}$ dalam kerak bumi adalah $12,5 \mathrm{mg} / \mathrm{kg}$ atau menurut Louma dan Rainbow, 2008 sebesar $14 \mathrm{mg} / \mathrm{kg}$ dan menurut Effendi, 2003 sebesar $15 \mathrm{mg} \cdot \mathrm{kg}^{-1}$. Canadian Council of Ministers for the Environment (CCME, 2002) menyatakan bahwa nilai ambang batas logam $\mathrm{Pb}$ dalam sedimen untuk perlindungan biota adalah sebesar $35 \mathrm{mg} / \mathrm{kg}$ berat kering dengan demikian perairan di sekitar lokasi penelitian masih aman bagi kelangsungan hidup biota. Baku mutu menurut US NOAA bahwa konsentrasi logam berat $\mathrm{Pb}$ dalam sedimen yang aman bagi biota (ERL; Effect Range Low) atau konsentrasi logam berat Pb dalam sedimen yang tidak memberikan efek negatif bagi biota sebesar $46,7 \mathrm{mg} / \mathrm{kg}$ dan konsentrasi yang sudah bisa memberikan efek negatif bagi biota (ERM; Effect Range Medium) sebesar $218 \mathrm{mg} / \mathrm{kg}$ (Turki, 2007), maka berdasarkan hal tersebut konsentrasi $\mathrm{Pb}$ di lokasi penelitian masih aman bagi kelangsungan hidup biota.

Konsentrasi logam berat $\mathrm{Zn}$ dalam sedimen tertinggi diperoleh di titik 3 pada zona perairan sungai yaitu sebesar 79,275 $\mathrm{mg} / \mathrm{kg}$ berat kering. Besarnya konsentrasi Zn di titik ini diduga karena keberadaan bendungan menyebabkan pola aliran air dari sungai tertahan sehingga terjadi deposisi partikel sehingga logam terakumulasi cukup tinggi dalam sedimen. Adapun konsentrasi Zn terendah berada pada titik 4 yaitu sebesar $48,284 \mathrm{mg} / \mathrm{kg}$ berat kering yang merupakan zona perairan estuaria (Gambar 2).

Tingginya konsentrasi logam berat Zn dalam sedimen diduga terutama berasal dari hasil pelapukan dan pengikisan batuan di lahan atas yang kemudian terbawa oleh aliran air sungai baik sebagai logam berat terlarut maupun berbentuk partikulat. Adapun input lain yang ikut menyumbang logam berat $\mathrm{Zn}$ adalah dari aktivitas pemukiman dan pertanian.

Distribusi dan akumulasi logam berat Zn dalam sedimen menunjukkan pola yang cenderung sama dengan logam berat $\mathrm{Pb}$ dimana konsentrasi terendah diperoleh pada zona perairan estuaria dan konsentrasi tinggi ditemukan pada zona perairan sungai. Kondisi ini menunjukkan bahwa penurunan konsentrasi logam Zn dalam estuaria disebabkan karena mekanisme filter (penyaringan) yang yang terjadi secara alami di titik batas atas bendungan. Mekanisme filter ini terutama diperankan oleh keberadaan partikel tersuspensi yang mengadsorpsi logam terlarut dalam kolom

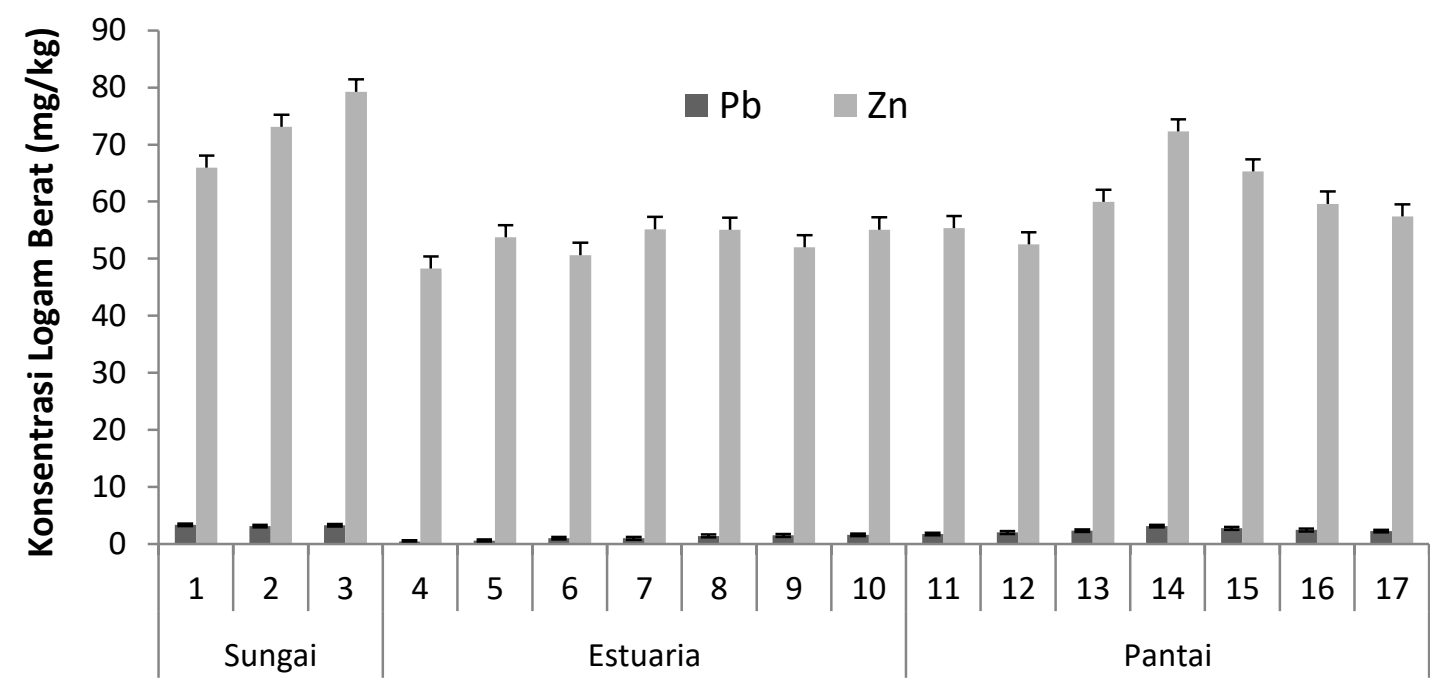

Titik Sampling

Gambar 2. Konsentrasi logam berat Pb dan Zn dalam sedimen di tiga zona perairan. 
air yang kemudian terdeposisi ke dasar perairan sungai sehingga logam berat yang terdistribusi masuk ke estuaria menurun drastis.

Konsentrasi logam berat $\mathrm{Zn}$ dalam sedimen pada pada zona perairan sungai (titik 2 dan 3) dan pantai (14) lebih besar dibanding kadar alami logam berat dalam sedimen berdasarkan Mohiuddin et al., 2010 dan Effendi, 2003 yang menyatakan bahwa konsentrasi alami Zn dalam kerak bumi adalah $70 \mathrm{mg} / \mathrm{kg}$. Adapun konsentrasi logam berat $\mathrm{Zn}$ di zona perairan estuaria masih lebih kecil dibanding kadar alaminya. Bila menggunakan acuan Louma dan Rainbow, 2008 bahwa kadar alami logam berat Zn dalam kerak bumi sebesar $75 \mathrm{mg} / \mathrm{kg}$ maka hanya titik 3 yang melampaui kadar alami.

Canadian Council of Ministers for the Environment (CCME, 2002) menyatakan bahwa nilai ambang batas logam Zn dalam sedimen untuk perlindungan biota adalah sebesar $123 \mathrm{mg} / \mathrm{kg}$ berat kering, maka lokasi penelitian masih aman bagi kelangsungan hidup biota. Sedang baku mutu menurut US NOAA bahwa konsentrasi logam berat Zn dalam sedimen yang aman bagi biota (ERL; Effect Range Low) atau konsentrasi logam berat $\mathrm{Zn}$ dalam sedimen yang tidak memberikan efek negatif bagi biota sebesar $150 \mathrm{mg} / \mathrm{kg}$ dan konsentrasi ERM yaitu konsentrasi yang sudah bisa memberikan efek negatif bagi biota (ERM; Effect Range Medium) sebesar $410 \mathrm{mg} / \mathrm{kg}$ (Turki, 2007), maka lokasi penelitian menunjukkan bahwa kisaran konsentrasi Zn dalam sedimen belum memberikan efek negatif bagi biota.

Kisaran konsentrasi logam berat $\mathrm{Pb}$ dan Zn di lokasi penelitian lebih rendah jika dibanding dengan penelitian Rastina, 2012 di sungai Tallo tetapi sedikit lebih tinggi dibanding hasil penelitian Werorilangi et al., 2013. Sementara jika dibanding dengan hasil penelitian di beberapa lokasi di perairan lainnya di Indonesia maka kisaran konsentrasi $\mathrm{Pb}$ di lokasi penelitian cukup rendah sedang kisaran konsentrasi logam Zn termasuk tinggi kecuali hasil penelitian Lestari dan Budiyanto, 2013 di Perairan Gresik yang lebih tinggi (Tabel 2).

\section{Karakteristik Fisika Kimia Sedimen}

Tekstur sedimen di lokasi penelitian secara umum didominasi oleh fraksi pasir dengan kisaran antara 3-88 \% dengan ratarata persentase $57,324 \%$. Komponen fraksi sangat halus yang terdiri dari fraksi lempung (clay) dan lanau (silt) dengan kisaran dan rata-rata adalah 6-77\% $(27,882)$ dan 2-68 \% $(14,794)$ seperti disajikan pada Gambar 3. Komposisi tekstur pasir (sand) dominan di lokasi penelitian mengindikasikan bahwa pergerakan massa air di lokasi penelitian cukup kuat sehingga yang mengalami deposisi ke dasar perairan adalah tekstur yang lebih besar berupa pasir. Pernyataan ini diperkuat oleh Perillo (1995) bahwa perairan dengan pergerakan massa air yang kuat mempunyai tekstur yang lebih besar berupa pasir.

Pola sebaran fraksi pasir (sand) menunjukkan persentase terendah diperoleh pada zona perairan pantai dan persentase tertinggi terdapat pada zona perairan estuaria. Adapun pola sebaran fraksi halus (clay dan silt) menunjukkan persentase tekstur halus (clay) yang terendah didapatkan pada zona perairan sungai dan silt terendah pada zona perairan estuaria, sedang persentase tertinggi fraksi clay dan silt ditemukan di perairan pantai.

Secara umum pada zona perairan dengan pergerakan arus yang lemah, maka partikel halus akan terdeposisi ke dasar perairan sehingga fraksi halus akan lebih dominan ditemukan. Kondisi ini banyak ditemukan pada perairan laut dengan pola aliran cenderung laminar sehingga mempengaruhi angkutan partikel kasar dari sungai serta pengaruh dinamika pantai sudah sangat kecil. Sebaliknya, fraksi sedimen berupa pasir (sand) dominan dijumpai pada zona estuaria karena zona perairan ini pergerakan massa air yang cukup kuat terutama pengadukan massa air (turbulensi) sehingga partikel berukuran halus tidak dapat terdeposisi dan yang mengendap hanya partikel berukuran besar.

Karakter perairan yang didominasi tekstur sedimen yang halus memiliki kecenderungan mengikat logam berat lebih 
tinggi dibanding tekstur sedimen yang kasar, begitupun dengan kandungan organik karbon yang lebih tinggi akan mengikat lebih banyak logam berat. Demikian pula halnya dengan peranan nilai potensial redoks yang menentukan mekanisme reaksi oksidasi reduksi dalam pengikatan dan pelepasan logam berat.
Stecko dan Bendell-Young (2000) bahwa ketersediaan logam berat dalam sedimen sangat berkaitan erat dengan sifatsifat dan Ukuran sedimen. Sedimen yang mengandung jumlah mineral lempung (clay) dan bahan organik akan cenderung mengakumulasi logam lebih tinggi, karena senyawa-senyawa tersebut memiliki sifat

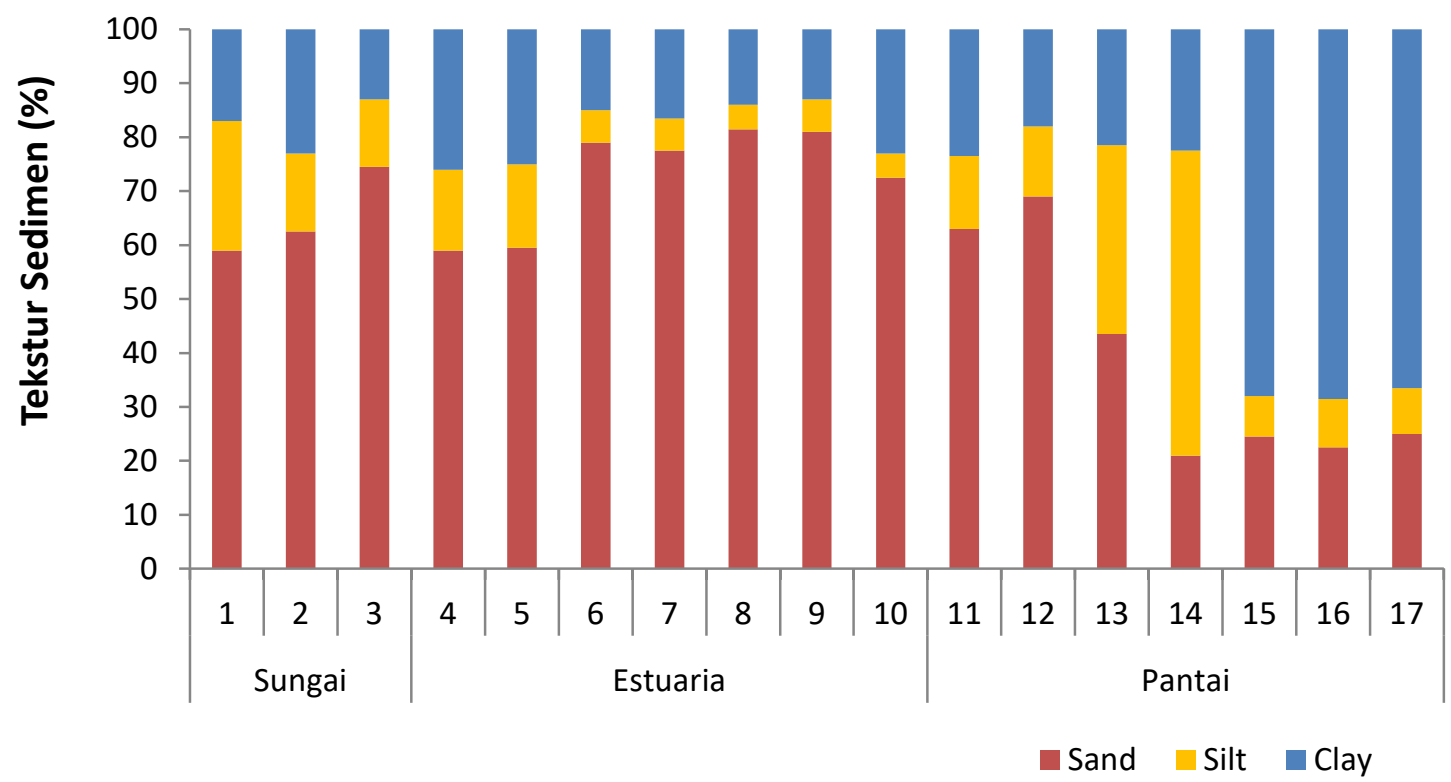

Titik Sampling

Gambar 3. Komposisi tekstur sedimen (\%) di tiga zona perairan berbeda

Tabel 2. Perbandingan hasil penelitian konsentrasi logam berat $\mathrm{Pb}$ dan $\mathrm{Zn}$ dalam sedimen ( $\mathrm{mg} / \mathrm{kg}$ berat kering) di beberapa lokasi perairan di dunia.

Referensi

\section{Penelitian ini}

Werorilangi et al. 2013

Ahmad, 2013

Lestari dan Budiyanto, 2013

Armid et al. (2014)

Tornero et al. (2014)

Bastami et al. (2015)

Hu et al. (2015)

Jiang et al. (2015)

Parra et al. (2015)

Al-Rashdi et al. (2015)

Liv et al. 2015)

Xu et al. (2015)

Wu et al. (2016)

Komalasari et al. (2019)

Suryono et al. (2019)
Lokasi Penelitian

$\mathrm{Pb}$

Zn

\section{Perairan Jeneberang}

Perairan Pantai Kota Mks

Pulau Bangka

Perairan Gresik

Teluk Kendari

Esturaia Guadalquivir

Laut Caspia, Iran

Sungai Changjiang

Laut Kuning (Yellow Sea)

Teluk Quintero, Chile

Perairan Pantai Abu Dhabi

Estuaria Yangtze

Perairan Pantai Shandong Utara,

Peninsula

Teluk Bohai

Teluk Klabat

Muara Sungai Kota Semarang
0,449-3,330

$0,38-2,58$

5,794

$1,74-12,70$

$0,84-17,02$

$30-54$

$7,13-13,00$

$13,5-35,5$

$4,31-21,9$

$17-36$

1,9

28

$11,0-26,3$

16- 49

$7,15-7,73$
48,284-79,275

$0-107,49$

16,706

$77,3-405,0$

$69-190$

$26,95-28,00$

$47,2-124$

$18,8-96,2$

65-167

8,2

70

$40,5-89,8$

75- 288
5-18 
mengikat logam. Komponen hasil oksida besi, mangan dan bahan organik merupakan komponen geokimia yang paling penting dalam mengontrol pengikatan logam-logam berat dalam sedimen estuaria.

Fraksi sangat halus (clay dan silt) lebih memiliki kemampuan berikatan dengan logam berat karena semakin halus tekstur maka luas permukaannya semakin besar sehingga kapasitas untuk berikatan dengan logam juga makin besar. Selain itu, fraksi sangat halus juga memiliki kemampuan berikatan dengan bahan organik sehingga logam dengan bahan organik akan membentuk ikatan kompleks dalam sedimen. Sebagaimana Sanusi, (2006) menyatakan bahwa konsentrasi logam berat dalam sedimen umumnya lebih tinggi pada sedimen berupa liat, lumpur, pasir berlumpur, dan campuran ketiganya dibanding sedimen berupa pasir murni. Hal ini disebabkan oleh adanya gaya tarik elektro kimia partikel sedimen yang lebih kuat pada sedimen yang lebih halus.

Oleh karena itu, berdasarkan data dan analisis yang dikemukan di atas maka diketahui bahwa wilayah perairan yang mengalami deposisi paling besar terjadi di perairan dengan pola aliran laminar (stabil) yaitu di perairan pantai. Dengan demikian, potensi akumulasi logam berat paling besar terdapat pada wilayah perairan yang memiliki karakter tekstur yang lebih halus berupa clay dan silt yaitu dimulai dari mulut estuaria ke perairan pantai.

Kandungan karbon organik berkisar antara 1,63-3,25 \% dengan rata-rata sebesar $2,159 \%$ seperti disajikan pada Gambar 4. Sumber karbon organik dalam sedimen dalam perairan berasal dari aliran sungai baik dalam bentuk terlarut maupun berasosiasi dengan partikel tersuspensi dan sebagian dari laut. Namun sumber utamanya berasal dari partikel yang mengikat karbon organik. Hal ini sesuai dengan yang dikemukan oleh Kemp (1989) bahwa kebanyakan bahan organik berbentuk partikulat yang kemudian mengendap di permukaan sedimen sehingga dapat meningkatkan konsentrasi bahan organik dalam sedimen.
Distribusi kandungan bahan organik cenderung stabil di ketiga zona perairan sungai, estuaria, dan pantai meski terlihat terdapat kecenderungan lebih rendah di estuaria. Distribusi yang karbon organik yang merata terjadi karena sumber utama karbon organik di dalam perairan berasal dari karbon organik bentuk partikulat yang berasal dari daratan hasil erosi lahan atas terbawa oleh sungai. Adapun kecenderungan rendah di estuaria karena sumber karbon organik bentuk partikulat mengalami deposisi di atas bendungan yang merupakan batas wilayah perairan sungai. Kandungan maksimum ditemukan pada titik 14 yang merupakan wilayah perairan pantai. Tingginya kandungan karbon organik pada pada titik 14 diduga karena wilayah perairan pantai di bagian utara Jeneberang terdapat sejumlah aktivitas yang dapat menyumbang buangan bahan organik seperti restoran, rumah makan, hotel, rumah sakit dan aktivitas pelabuhan. Sumber karbon organik dalam perairan juga berasal dari aliran sungai baik dalam bentuk terlarut maupun berasosiasi dengan partikel tersuspensi dan dari hasil dekomposisi dan eksresi organisme laut.

Kondisi perairan di sekitar Jeneberang hanya berupa hamparan pasir tanpa keberadaan mangrove menyebabkan suplai bahan organik yang berasal dari jatuhan serasah pohon mangrove berupa daun, ranting, cabang, dan buah tidak ada sehingga input bahan organik ke dalam perairan estuaria sangat kecil. Karbon organik dalam sedimen memiliki kemampuan untuk berikatan dengan logam berat. Karbon dalam sedimen membentuk ikatan komplek (complexation) dengan logam berat, sehingga semakin tinggi konsentrasi karbon organik dalam sedimen, maka semakin tinggi konsentrasi polutan logam berat dalam sedimen, seperti yang diungkapkan oleh Sanusi, 2006 bahwa kandungan bahan organik memiliki hubungan yang positif dengan konsentrasi logam berat dalam sedimen.

Potensial redoks (Eh) merupakan sifat elektrokimia yang dapat dipakai sebagai indikasi dalam mengukur derajat an-aerobik tanah dan tingkat transformasi biogeokimia yang terjadi. Nilai potensial redoks sedimen di 


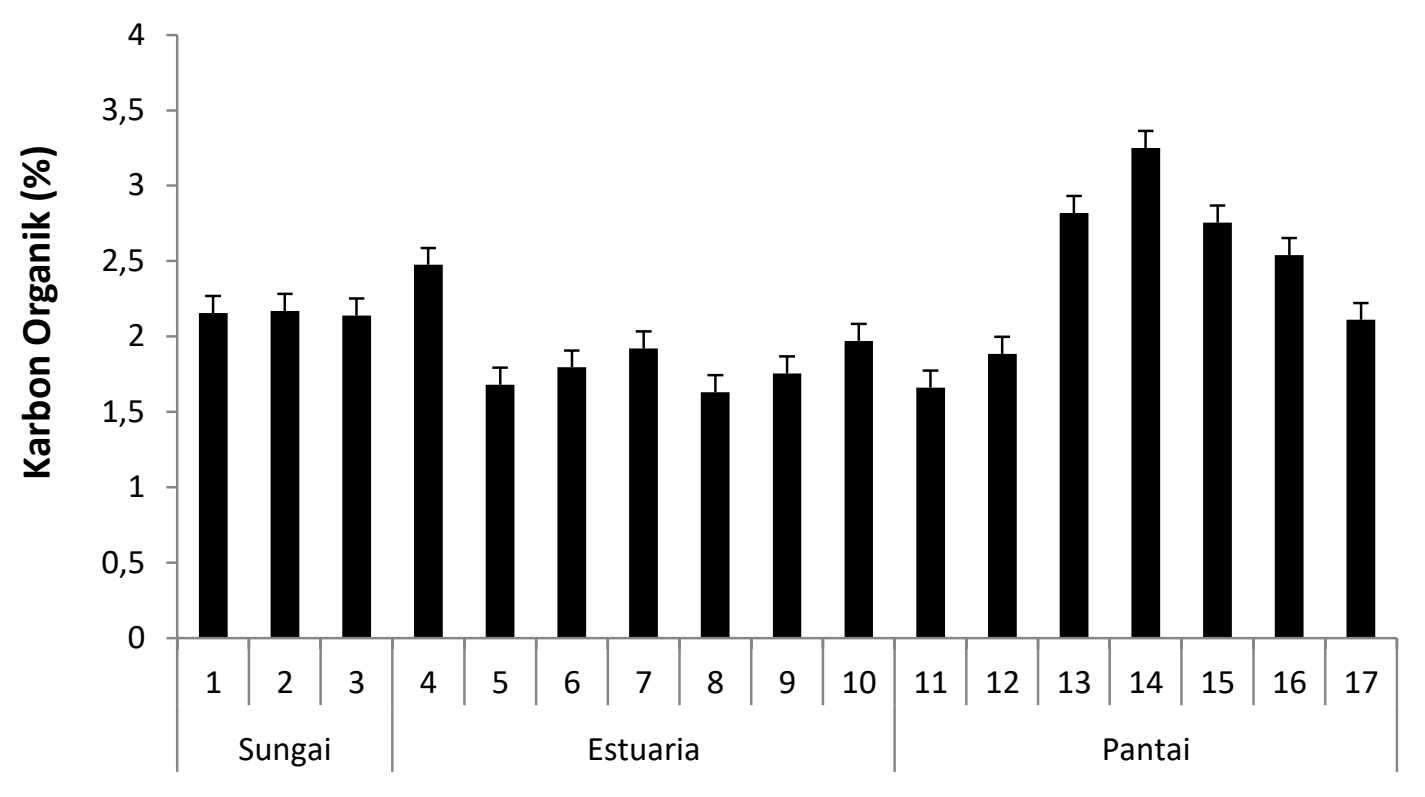

Titik Sampling

Gambar 4. Kandungan karbon organik (\%) dalam sedimen di tiga zona perairan berbeda

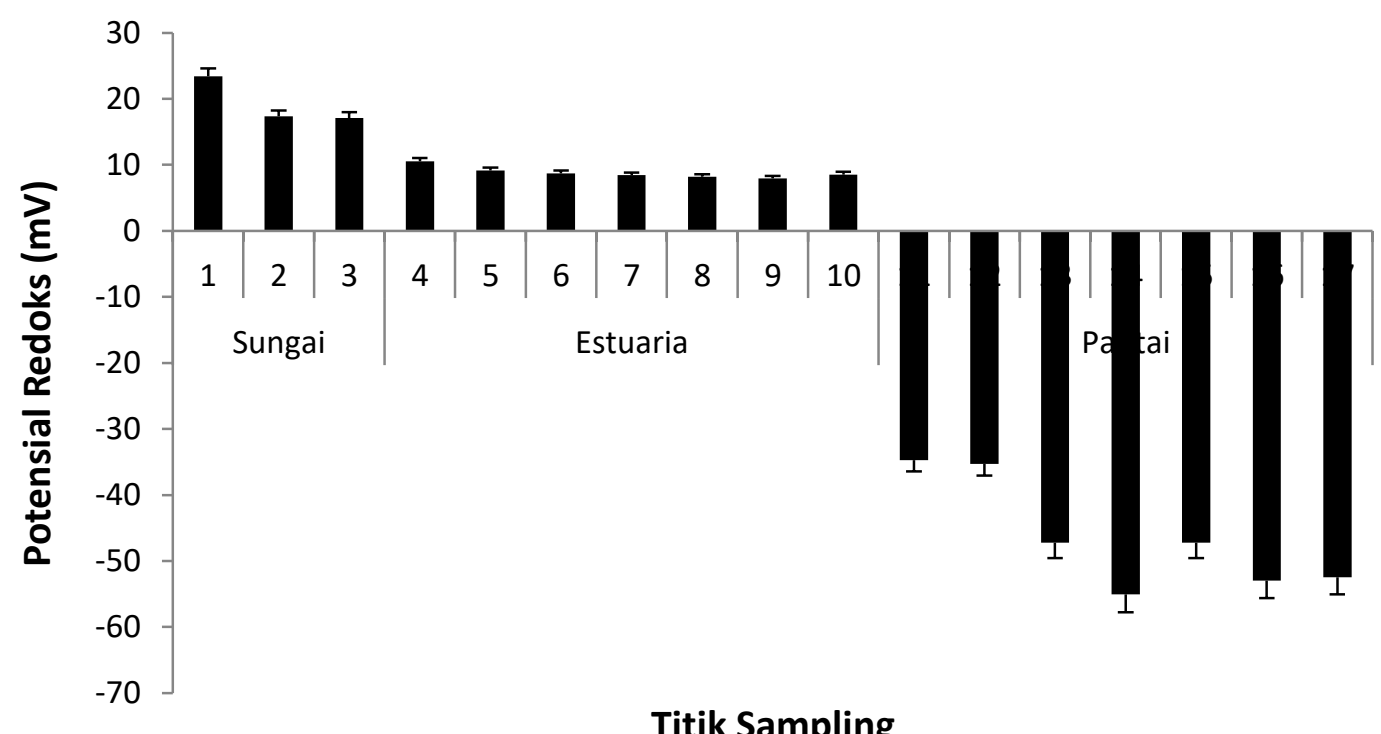

Gambar 5. Nilai potensial redoks sedimen $(\mathrm{mV})$ di tiga zona perairan berbeda

lokasi penelitian berkisar antara -52,43 sampai $23,43 \mathrm{mV}$, termasuk kategori zona reduksi dan transisi atau berada pada kondisi anaerob dan aerob, seperti disajikan pada Gambar 5. Odum (1998) mengelompokkan sedimen dasar suatu perairan menjadi 3 zona yang didasarkan pada nilai potensial redoks. Ketiga zona tersebut adalah zona oksidasi dengan nilai Eh $>200 \mathrm{mV}$, zona transisi dengan nilai Eh antara $0-200 \mathrm{mV}$ dan zona reduksi dengan nilai Eh $<0$.

Perubahan suasana oksidatif ke reduktif mengakibatkan terjadinya perubahan bentuk besi, dari feri tereduksi menjadi fero dan masuk ke dalam sedimen. Pada kondisi 
anaerob, mikroorganisme fakultatif dan obligatif akan menggunakan oksidan anorganik selain oksigen sebagai akseptor elektron, seperti $\mathrm{NO}_{3}{ }^{-} \mathrm{Mn}^{4+}, \mathrm{Fe}^{3+}, \mathrm{CO}_{2}, \mathrm{~N}_{2}$ dan $\mathrm{H}^{+}$, yang kemudian akan direduksi berturtturut menjadi $\mathrm{N}_{2}, \mathrm{Mn}^{2+}, \mathrm{Fe}^{2+}, \mathrm{H}_{2} \mathrm{~S}, \mathrm{CH}_{4}, \mathrm{NH}_{4}{ }^{+}$, dan $\mathrm{NH}_{2}$.

Mangan oksida dan besi oksida dalam sedimen mempengaruhi kandungan dan asosiasi logam berat dalam sedimen. Feoksida dan Mn-oksida dalam keadaaan oksidasi dapat menyerap kation dan anion dari larutan serta logam dalam air terutama logam runutan. Dalam keadaan reduksi logam yang terserap dapat diremobilisasi kembali ke larutan dan bertindak sebagai sumber logam dalam perairan, namun logam yang terikat oleh fraksi sedimen akan mengalami diagenesis yang menyebabkan peningkatan bobot molekul dan hilangnya gugus fungsi (Connel dan Miller, 1995).

Zona reduksi yang terdapat pada perairan pantai terutama titik yang jauh dari garis pantai disebabkan karena kurangnya sirkulasi massa air (alirannya lambat dan polanya laminar) sehingga terjadi deplesi oksigen (kadar oksigen menurun). Pada perairan estuaria dibanding sungai dan pantai, potensial redoks lebih tinggi karena di perairan estuaria terjadi pengadukan massa air (pola aliran turbulen) akibat pertemuan massa air laut dan sungai yang berbeda densitasnya. Zona reduksi juga bisa terjadi akibat adanya aktivitas bakteri yang membutuhkan oksigen dalam mendegradasi bahan organik.

Penurunan nilai potensial redoks sedimen ke arah laut disebabkan oleh peningkatan $\mathrm{pH}$ ke arah laut dan penurunan itu semakin tajam ketika kandungan bahan organik tinggi dalam sedimen dan siklus pergerakan massa air kecil serta pertambahan kedalaman. Kondisi itu terlihat pada titik 14-17 yang berada pada perairan laut dengan titik sampling paling luar. Penurunan nilai potensial redoks disebabkan adanya kontribusi bahan organik ke dalam sedimen, baik gugus hidroksil maupun senyawa karbosil lainnya yang dapat memberi keseimbangan terhadap aktivitas ion $\mathrm{H}^{+}$sehingga menyebabkan menurunnya konsentrasi ion $\mathrm{H}^{+}$.
Penurunan nilai potensial redoks juga mendorong berkurangnya jumlah elektron dalam sedimen. Jumlah elektron berbanding lurus dengan potensial redoks sehingga penurunan jumlah elektron secara otomatis menurunkan pula nilai Eh. Perairan dalam juga dicirikan dengan kondisi deplesi $\mathrm{O}_{2}$ sehingga diikuti oleh penurunan nilai potensial redoks sebagaimana Rhoads (1974), bahwa konsentrasi oksigen dalam sedimen berhubungan erat dengan nilai potensial redoks (Eh) sedimen. Nilai Eh +400 $\mathrm{mV}$, konsentrasi oksigennya antara 4-10 mg/l. Sedangkan pada nilai Eh $+300 \mathrm{mV}$, konsentrasi oksigen sekitar $0.3 \mathrm{mg} / \mathrm{l}$ dan pada +200 mV, oksigennya sekitar $0.1 \mathrm{mg} / \mathrm{l}$, konsentrasi oksigen menjadi tidak terukur jika nilai Eh di bawah $0 \mathrm{mV}$.

Peningkatan nilai pH dapat terjadi karena adanya kontribusi bahan organik yang melepaskan ion $\mathrm{OH}^{-}$karena terjadi proses reduksi. Demikian pula keberadaan ion $\mathrm{Fe}^{+3}$ dalam sedimen tereduksi berubah menjadi $\mathrm{Fe}^{+2}$ sehingga berpeluang melepaskan $\mathrm{OH}^{-}$dan meningkatkan $\mathrm{pH}$ sedimen atau menurunkan Eh. Mekanisme reaksi oksidasi-reduksi dalam sedimen ditentukan oleh ketersediaan oksigen terlarut dalam air jebakan (interstitial water) dan $\mathrm{pH}$ sedimen. Pada kondisi oksigen rendah akan terjadi reaksi reduksi sehingga senyawa kimia yang terbentuk adalah $\mathrm{H}_{2} \mathrm{~S}, \mathrm{CH}_{4}, \mathrm{NH}_{3}, \mathrm{~N}_{2}, \mathrm{Fe}^{2+}$, dan $\mathrm{Mn}^{2+}$ yang bereaksi membentuk endapan kompleks. Pada kondisi oksigen cukup tersedia akan terjadi reaksi oksidasi dimana senyawa kimia yang terbentuk adalah $\mathrm{SO}_{4}{ }^{2-}, \mathrm{CO}_{2}, \mathrm{CO}_{3}{ }^{2-}, \mathrm{NO}_{3}{ }^{-}, \mathrm{Fe}^{3+}$ dan $\mathrm{Mn}^{4+}$ yang bereaksi membentuk endapan kompleks (Parsons dan Takahashi, 1977 dalam Sanusi, 2006).

\section{Pengaruh Karakteristik Fisika Kimia Sedimen terhadap Distribusi dan Akumulasi Logam Berat $\mathrm{Pb}$ dan $\mathrm{Zn}$}

Hasil analisis regresi dan korelasi terhadap beberapa parameter yang mempengaruhi distribusi dan akumulasi logam berat $\mathrm{Pb}$ dan $\mathrm{Zn}$ dalam sedimen menunjukkan hubungan yang linier atau berbanding lurus antara tekstur sedimen halus dan kandungan organik karbon dengan konsentrasi logam berat dalam sedimen, tetapi korelasi nilai potensial redoks 
dan tekstur kasar terhadap distribusi dan akumulasi logam berat $\mathrm{Pb}$ dan $\mathrm{Zn}$ dalam sedimen berbanding terbalik. Artinya, semakin besar persentase tekstur sedimen yang berukuran halus dan tingginya kandungan karbon organik dalam sedimen maka semakin besar pula konsentrasi dan akumulasi logam berat yang terikat dalam sedimen, namun semakin kecil nilai potensial redoks dan tekstur kasar maka konsentrasi logam berat dalam sedimen semakin besar. Sanusi (2006) menyatakan bahwa kandungan bahan organik memiliki hubungan yang positif dengan konsentrasi logam berat dalam sedimen.

Persamaan regresi yang diperoleh menunjukkan bahwa karakteristik fisika kimia sedimen yang paling berpengaruh terhadap distribusi dan akumulasi logam berat $\mathrm{Pb}$ dan Zn dalam sedimen di lokasi penelitian adalah kandungan karbon organik. Peranan karbon organik dalam mengikat logam berat terjadi melalui pembentukan ikatan kompleks antara logam berat dan karbon organik terutama dalam hal ini yang paling berperan adalah asam humus (humic acid). Chester (1990) menyatakan bahwa reaktivitas biogeokimia dalam perairan alami diatur oleh sejumlah parameter fisika-kimia seperti: $\mathrm{pH}$, redoks potensial, salinitas, konsentrasi complexing ligand, berbagai jenis nutrien, komponen organik dan bahanbahan partikulat. Demikian pula Togwell (1979), bahwa konsentrasi logam berat pada sedimen, tidak saja ditentukan oleh proses pelapukan batuan, tetapi juga dipengaruhi oleh komposisi mineral dan ukuran (partikel) endapan sedimen. Faktor berpengaruh berikutnya berturut-turut adalah tekstur sedimen dan potensial redoks.

Nilai keeratan hubungan antara distribusi dan akumulasi logam berat $\mathrm{Pb}$ dalam sedimen dengan parameter tekstur, kandungan karbon organik, dan potensial redoks ditunjukkan dengan nilai $\mathrm{R}^{2}$ sebesar 0,765 hal ini menunjukkan bahwa keeratan hubungannya cukup tinggi, sedang untuk logam $\mathrm{Zn}$ diperoleh nilai $\mathrm{R}^{2}$ sebesar 0,586 juga menunjukkan adanya keeratan hubungan. Distribusi dan akumulasi logam berat dalam sedimen di suatu wilayah perairan ditentukan oleh beberapa faktor seperti proses pelapukan batuan, endapan partikel sedimen, status redoks, konsentrasi karbon organik, berbagai jenis nutrien, tekstur sedimen, dan bioturbasi (Chester, 1990; Togwell, 1979; Meador et al. 1998; Stecko dan Bendell-Young, 2000). Demikian pula, perubahan kondisi lingkungan seperti $\mathrm{pH}$, suhu, dan potensial redoks dapat menyebabkan lepasnya ikatan logam berat dari permukaan partikel dan menjadi logam terlarut sehingga mengubah peran sedimen yang semula menjadi sink (penyerap) logam berat menjadi source (sumber) logam berat di dalam perairan (Wang et al. 2015).

\section{KESIMPULAN}

Distribusi dan akumulasi logam berat $\mathrm{Pb}$ dan $\mathrm{Zn}$ menunjukkan pola yang serupa dimana diperoleh konsentrasi paling rendah di perairan estuaria dan konsentrasi tinggi pada perairan pantai dan sungai. Parameter tekstur, kandungan organik karbon dalam sedimen, dan potensial redoks sedimen memberikan pengaruh terhadap distribusi dan akumulasi logam berat $\mathrm{Pb}$ dan $\mathrm{Zn}$ dalam sedimen. Distribusi dan akumulasi logam berat $\mathrm{Pb}$ dan $\mathrm{Zn}$ dalam sedimen menunjukkan hubungan yang linier atau berbanding lurus antara tekstur sedimen halus dan kandungan karbon organik, namun korelasi nilai potensial redoks sedimen dan tekstur sedimen kasar terhadap distribusi dan akumulasi logam berat $\mathrm{Pb}$ dan $\mathrm{Zn}$ dalam sedimen berbanding terbalik. Parameter yang paling berpengaruh terhadap distribusi dan akumulasi logam berat $\mathrm{Pb}$ dan $\mathrm{Zn}$ dalam sedimen adalah kandungan karbon organik.

\section{DAFTAR PUSTAKA}

Ahmad, F. 2013. Distribusi dan Prediksi Tingkat Pencemaran Logam Berat (Pb, $\mathrm{Cd}, \mathrm{Cu}, \mathrm{Zn}$, dan Ni) dalam Sedimen di Perairan Pulau Bangka Menggunakan Indeks Beban Pencemaran dan Indeks Geoakumulasi. Jurnal Jurnal IImu dan Teknologi Kelautan Tropis Vol. 5, No. 1, Juni 2013:170. doi : 10.29244/jitkt.v5i 1

Al-Rashdi, S., Arabi, A.A., Howari, F.M., \& Siad, A. 2015. Distribution of heavy metals in the coastal area of Abu Dhabi in the United Arab Emirates. Mar Pollut Bull 97, 494-498. doi : 10.1016/j.marpolbul.2015. 05.052 
Arifin, Z. 2008. Nasib kontaminan logam dan implikasinya pada komunitas bentik di Delta Berau, Kalimantan Timur. Laporan akhir kumulatif Riset Kompetitif Tahun 2006-2008. Puslit Oseanografi-LIPI. Jakarta.

Arifin, Z. 2011 . Konsentrasi Logam Berat di Air, Sedimen, dan Biota di Teluk Kelabat, Pulau Bangka. Jurnal Ilmu dan Teknologi Kelautan Tropis, 3(1):104. doi : 10.29244/ji tkt.v3i 1

Armid, A, Shinjo, R, Zaeni, A, Sani, A., \& Ruslan, R. 2014. The distribution of heavy metals including $\mathrm{Pb}, \mathrm{Cd}$ and $\mathrm{Cr}$ in Kendari Bay surficial sediments. Mar Pollut Bull 84, 373378. doi : 10.1016/j.marpolbul.2014.05.021

Bastami, K.D, Bagheri, H, Kheirabadi, V, Zaferani, G.G, Teymori, M.B, Hamzehpoor, A, Soltani F, Haghparast, S, Harami, S.R.M, Ghorghani, N.F., \& Ganji, S. 2015. Distribution and ecological risk assessment of heavy metals in surface sediments along southeast coast of the Caspian Sea. Marine Pollution Bulletin, 81: 262-267. doi: 10.1016/j.marpolbul.2014. 01.029

Bryan, G.W. \& Langston, W.J. 1992. Bioavailability, accumulation and effects of heavy metals in sediments with special reference to United Kingdom estuaries: a review. Environ. Pollut. (76): 89-131. doi : 10.1016/0269-7491 (92)90099-V

Canadian Council of Ministers for the Environment (CCME). 2002. Canadian Sediment Quality Guidelines for the Protection of Aquatic Life Summary Table.CCME. Winnipeg, MB. 7p.

Chester, R. 1990. Marine Geochemistry. Unwin Hyman, London, England.

Connel, D.W \& Miller, J.G. 1995. Kimia dan Ekotoksikologi Pencemaran. Diterjemahkan oleh Yanti Koestoer. Penerbit UI Press Press. Jakarta.

Effendi, H. 2003. Telaah Kualitas Air. Bagi Pengelolaan Sumber Daya dan Lingkungan Perairan. Penerbit Kanisius, Yogyakarta.

Hamzah, F. \& Setiawan, A. 2010. Akumulasi Logam Berat $\mathrm{Pb}, \mathrm{Cu}$, dan $\mathrm{Zn}$ di Hutan Mangrove Muara Angke, Jakarta Utara. Jurnal Ilmu dan Teknologi Kelautan Tropis, 2(2):41-52. doi : doi.org/10.29244/jitkt.v2i2
Hu, B.Q., Cui, R.Y., Li, J., Wei, H.L., Zhao, J.T., Bai, F.L., Song, W.Y. \& Ding, X. 2015. Occurrence and distribution of heavy metals in surface sediments of the Changhua River Estuary and adjacent shelf (Hainan Island). Marine Pollution Bulletin, 76, 400-405. doi : 10.1016/j.mar polbul.2013.08.020

Jiang, X., Teng, A., XU, W. \& Liu, X. 2015. Distribution and pollution assessment of heavy metals in surface sediments in the Yellow Sea. Marine Pollution Bulletin, 83: 366-375. doi : 10.1016/j.marpolbul.2014. 03.020

Kemp, W.M. 1989. Estuarine Chemistry. In Day, J.W., C.A.S. Hall, W.M. Kemp, and A. Yanez-Arancibia (eds): estuarine ecology, section II: physycal considerations. John Wiley and Sons, New York, USA.

Komalasari, A., Afriyansyah, B., Ihsan, M., \& Nugaraha, M.A. 2019. Bioakumulasi Logam Berat $\mathrm{Pb}$ dan $\mathrm{Cu}$ terhadap Penaeus merguiensis di Perairan Teluk Kelabat Bagian Dalam. Jurnal Kelautan Tropis, 22(1):1-8. doi : 10.14710/jkt.v0iO. 3727

Lenzi, M. 2008. Resuspension of Sediment as a Method for Managing Eutrophic Lagoons. Marine Pollution: New Research, Nova Science Publishers, Inc. New York.pp. 15-21.

Lestari \& Budiyanto, F. 2013. Konsentrasi Hg, $\mathrm{Cd}, \mathrm{Cu}, \mathrm{Pb}$, dan $\mathrm{Zn}$ dalam sedimen di Perairan Gresik. Jurnal Jurnal Ilmu dan Teknologi Kelautan Tropis 5(1):182. doi : https://doi.org/10.29244/jitkt.v5il

Lestari. 2011. Distribusi dan geokimia logam berat dalam sedimen di Perairan Semarang, Jawa Tengah. Prosiding Pertemuan IImiah Nasional Tahunan VIII ISOI 2011. Ikatan Sarjana Oseanologi Indonesia, 25-27 September 2011. Makassar. p204-217

Liu, Z., Pan, S. Sun Z., Ma, R., Chen, L., Wang, Y. \& Wang, S. 2015. Heavy metal spatial variability and historical changes in the Yangtze River estuary and North Jiangsu tidal flat. Marine Pollution Bulletin, 98:115129. doi: 10.1016/j.marpolbul.2015.07.006

Luoma, S.N. \& P.S. Rainbow. 2008. Metal Contamination in Aquatic Environments : 
Science and Lateral Management. Cambrdige University Press. New York. USA.

Meador, J.P., Robisch, P.A., Clark, R.C. \& Ernest, D.W. 1998. Element in fish and sediment from the Pacific Coast of the United States: result from the national benthic surveillance project. Marine Pollution Bulletin, 37(1-2): 56-66. doi : 10.1016/S0025-326X(98)89001-2

Mohiuddin, M.K., Zakir H.M., Otomo, K., Sharmin, S. \& Shikazono, N. 2010. Geochemical distribution of trace metal pollutants in water and sediments of downstream of an urban river. International Journal of Environmental Science and Technology, 7(1):17-28. doi : 10.1007/BF03326113

Najamuddin, Prartono, T., Sanusi, H.S. \& Nurjaya, I.W. 2016. Seasonal distribution and geochemical fractionation of heavymetals from surface sediment in a tropical estuary of Jeneberang River, Indonesia. Marine Pollution Bulletin, 111: 456-462. doi : 10.1016/j.marpolbul.2016. 06.106

Najamuddin \& Surahman. 2017. Dispersion, speciation, and pollution assessment of heavy metals $\mathrm{Pb}$ and $\mathrm{Zn}$ in surface sediment from disturbed ecosystem of Jeneberang Waters. IOP Conference Series: Earth and Environmental Science, Vol. 89. doi : 10.1088/1755-1315/89/1 1012030

Odum, E.P. 1993. Dasar-Dasar Ekologi. Gadjah Mada University Press. Yogyakarta.

Parra, S., Bravo, M.A., Quiroz, W., Querol, X., \& Paipa, C. 2015. Distribution and pollution assessment of trace elements in marine sediments in the Quintero Bay (Chile). Marine Pollution Bulletin, 99:256-263. doi : 10.1016/j.marpolbul.2015.07.066

Rabee, M.A., Al-Fatlawy, Y.F., Own, A.A.H.N.A. \& Nameer, M. 2011. Using Pollution Load Index (PLI) and Geoaccumulation Index (I-Geo) for the Assessment of Heavy Metals in Tigris River Sediment in Bagdad Region. J. of Al- Nahrain Universisty, 14(4):108-114. doi : 10.22401/JNUS.14.4.14

Rhoads, D.C. 1974. Organism-Sediment Relations. In Oceanography and Marine Biology. Barnes, H. (ed). George Allen and Unwin Ltd, London.
Samawi, M.F. 2007. Desain Sistem Pengendalian Pencemaran Perairan Pantai Kota. Studi Kasus Perairan Pantai Kota Makassar. Disertasi Sekolah Pascasarjana Institut Pertanian Bogor, Bogor.

Sanusi, H.S. 2006. Kimia Laut. Proses Fisik Kimia dan Interaksinya dengan Lingkungan. Departemen IImu dan Teknologi Kelautan. IPB, Bogor.

Stecko, J.R.P. \& Bendell-Young, L.I. 2000. Contrasting the geochemistry of suspended particulate matter and deposited sediments within an estuary. Applied Geochemistry, 15: 753-775. doi : 10.1016/S0883-2927(99)00090-6

Suryono, C.A., Pratikto, I. \& Rusmaharani, A. 2019. Logam Berat Anthropogenik Pb dan Cu pada Lapisan Sedimen Permukaan dan Dasar Muara Sungai di Kota Semarang, Jawa Tengah Indonesia. Jurnal Kelautan Tropis, 22(1):87-92. doi : 10.14710/jkt.v22i1.3223

Togwell, A.J. 1979. Source of heavy metals contamination in a river-lake system. Environmental Pollution, (18):131-138. doi : 10.1016/0013-9327(79)90088-0

Tornero, V., Arias, A.M. \& Blasco, J. 2014. Trace element contamination in the Guadalquivir River Estuary ten years after the Aznalcóllar mine spill. Marine Pollution Bulletin, 86:349-360. doi: 10.1016/j.marpol bul.2014.06.044

Turki, A.J. 2007. Metal Speciation (Cd, Cu, Pb and $\mathrm{Zn}$ ) in Sediments from Al Shabab Lagoon, Jeddah, Saudi Arabia. Marine Science, 18 : 191-210. doi : 10.4197/mar. 18-1.11

Walkley A, \& Black, L.A. 1934. An Examination of the Degtjareff Method for Determining Soil Organic Matter, and a Proposed Modification of the Chromic Acid Titration Method. Soil Science, 37(1):2938. doi : 10.1097/00010694-193401000-000 03.

Werorilangi, S., Tahir, A., Noor, A. \& Samawi, M.F. 2013. Status Pencemaran dan Potensi Bioavailibilitas Logam di Sedimen Perairan Pantai Kota Makassar. Makalah Seminar Nasional Perikanan, Universitas Hasanuddin, Makassar.

Wu, Q., Zhou, H., Tam, N.Y.F., Tian, Y., Tan, Y., Zhou, S., Li, Q., Chen, Y., Leung, J.Y.S. 2016. Contamination, toxicity and 
speciation of heavy metals in an industrialized urban river: Implications for the dispersal of heavy metals. Marine Pollution Bulletin, 104:153-161. doi : 10.1016/j.marpolbul.2016.01.043

Xu, G., Pei, S., Liu, J., Gao, M., Hu, G., Kong X. 2015. Surface sediment properties and heavy metal pollution assessment in the near-shore area, north Shandong Peninsula. Marine Pollution Bulletin, 95: 395-401. doi: 10.1016/j.marpolbul.2015.03. 040. 